\title{
Herbicides in Aquatic Systems
}

\author{
Lyn A. Gettys, William T. Haller and \\ Gregory E. MacDonald \\ Additional information is available at the end of the chapter \\ http://dx.doi.org/10.5772/56015
}

\section{Introduction}

Water plays a crucial role in maintaining the health of our global ecosystem. We rely on this valuable resource to provide drinking water, irrigation, and recreation; in addition, appropriate management of our waters is critical for flood control efforts. A diversity of native aquatic plants constitutes an integral part of the aquatic environment. These mixed populations of hydrophytes provide structure, habitat and food for fish, waterfowl, and other wildlife and act as nutrient sinks by removing phosphorus, nitrogen, and other elements from the water column. Many regions of the world - but especially those with mild climates - provide an ideal habitat for many organisms, including aquatic plants. Non-native aquatic plants are frequently introduced to aquatic systems through a number of pathways, including transport by animals, currents, or wind, but the majority of problematic plants are brought in as a result of anthropogenic activities. Human introduction of non-native aquatic plants may be accidental (e.g., via ballast water or as contaminants in desirable flora) or intentional.

\section{Aquatic weeds}

Many of the worst aquatic weed problems in the United States are the result of intentional introduction. For example, waterhyacinth [Eichhornia crassipes (Mart.) Solms] (Fig. 1) was reportedly introduced to the United States at the Southern States Cotton Expo in New Orleans in 1884. Visitors to the Expo were given waterhyacinth plants as souvenirs and many of these plants found their way into the waters of Louisiana, Texas, and Florida [1]. Local legend states that a Florida resident was entranced by the beautiful, showy flowers of this Amazonian native and brought plants back to his water garden near the St. Johns River. The plants grew abundantly and the backyard water gardener decided to share his "bounty of beauties" with 
others by tossing his extra plants into the St. Johns River [2]. Within a decade, the St. Johns was so clogged with waterhyacinths that navigation had become impossible [1-3].

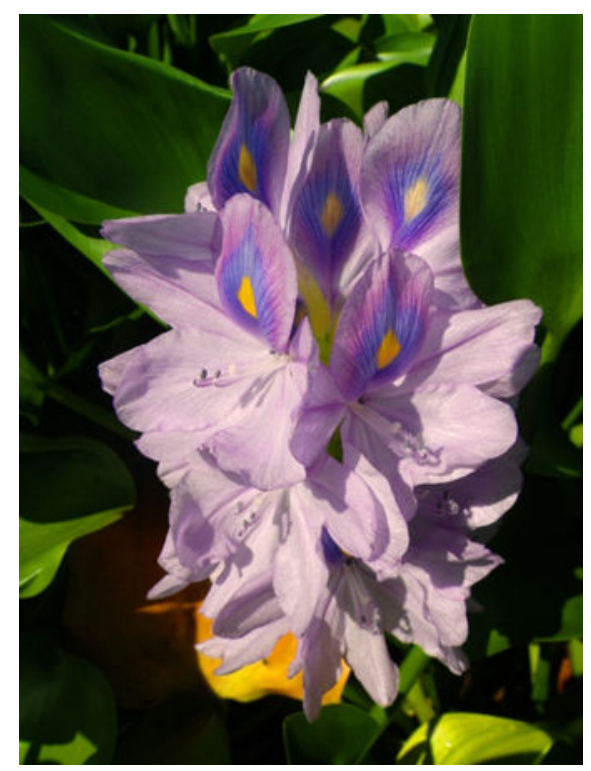

Figure 1. Waterhyacinth. Photo courtesy Lyn Gettys.

The St. Johns constituted a major shipping passage through Florida; in order to mitigate this important resource and make it available to commercial concerns for the transport of goods, the US Army Corps of Engineers was authorized by the US Congress to use "any means necessary" to clear the system of these noxious weeds [1]. Attempts to control floating waterhyacinths utilized applications of a wide variety of substances, including arsenic, sulfuric acid, and other toxic chemicals [1]. Some of these substances effectively controlled waterhyacinths, but proved toxic to cattle that grazed on treated plants [2]. Feeding deterrents such as rotten eggs and manure were added to chemical applications to discourage grazing, but were ultimately ineffective or too expensive to use under operational conditions [1]. After these disappointing results, resource managers were forced to resort to mechanical control manually removing plants from the surface of the water and offloading them to shore - in their attempts to clear Florida's waterways (Fig. 2). This method proved expensive and ineffective, as plants grew faster than they could be harvested from the system, but was the only management tool available until the discovery of synthetic herbicides in the 1940s [3]. Waterhyacinth is now controlled in many regions via chemical means (e.g., application of herbicides), but this Brazilian native is still considered one of the world's worst weeds $[4,5]$ and is intensively managed in virtually all areas the species has managed to invade. 


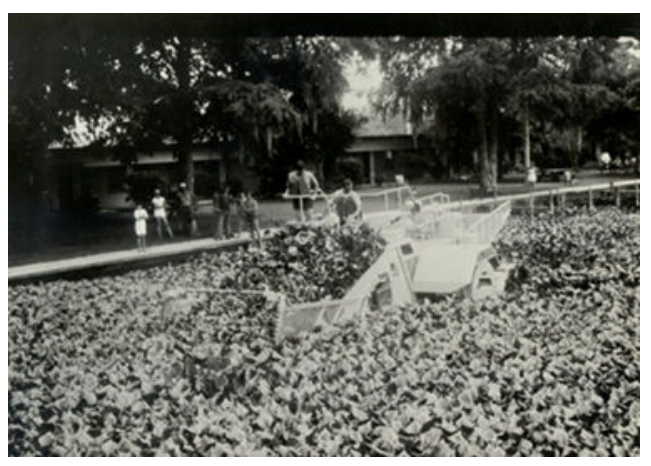

Figure 2. Mechanical harvesting of waterhyacinth. Photo courtesy UF/IFAS Center for Aquatic and Invasive Plants.

Floating weeds such as waterhyacinth are readily visible and many stakeholders understand the need to control these types of noxious species. Submersed invasive species, however, are often hidden from view and the problems associated with them are not readily apparent. Submersed weeds often go unnoticed until they form surface mats; by this point, plants have been growing unchecked, often for months, and the water column is filled with plant material. This is often the case with hydrilla [Hydrilla verticillata) (L.f.) Royle] (Fig. 3), a noxious invader with multiple centers of origin that has been called the world's worst weed [6]. Hydrilla was introduced to the United States intentionally via the aquarium industry [7], and historical accounts suggest that some aquarium plant dealers cultivated hydrilla in canals and waters near their nurseries to have a ready supply of plant material for their customers [8]. However, the species has undoubtedly been introduced to the country's waterways repeatedly, as hobbyists regularly dispose of extra aquarium plants by tossing them in the nearest body of water. Because hydrilla is able to root from extremely small fragments [9], other pathways of introduction include waterfowl, other fauna and recreational equipment such as boats and trailers. Hydrilla causes a host of problems in its regions of invasion and greatly reduces ecosystem services and anthropogenic uses of aquatic resources.

Hydrilla can reportedly grow 1 inch $(2.5 \mathrm{~cm})$ per day [6], but most researchers agree that this is a gross underestimate of the plant's actual productivity [10]. This noxious weed wreaks havoc on the ecosystem by forming monocultures [11], which serve as poor habitat for resident fauna. Dense plant growth traps heat, raises the temperature of surface water and depletes dissolved oxygen, resulting in conditions that negatively impact fish survival $[12,13]$. Hydrilla also obstructs water flow, which can have catastrophic consequences if resource managers need to quickly move water to prevent flooding during tropical storms, hurricanes, and other severe weather events. Recreational uses of hydrilla-infested waters are limited as well; boats motors quickly become clogged and strangled with weeds (Fig. 4), fishing lines are snagged within moments of being cast, and swimmers have reportedly drowned after becoming entangled in hydrilla [14]. Hydrilla is intensively managed in its regions of invasion. Populations of this submersed weed are reduced by a number of means, including mechanical harvesting, hand-pulling, benthic barriers, and biological control organisms such as Asian or 


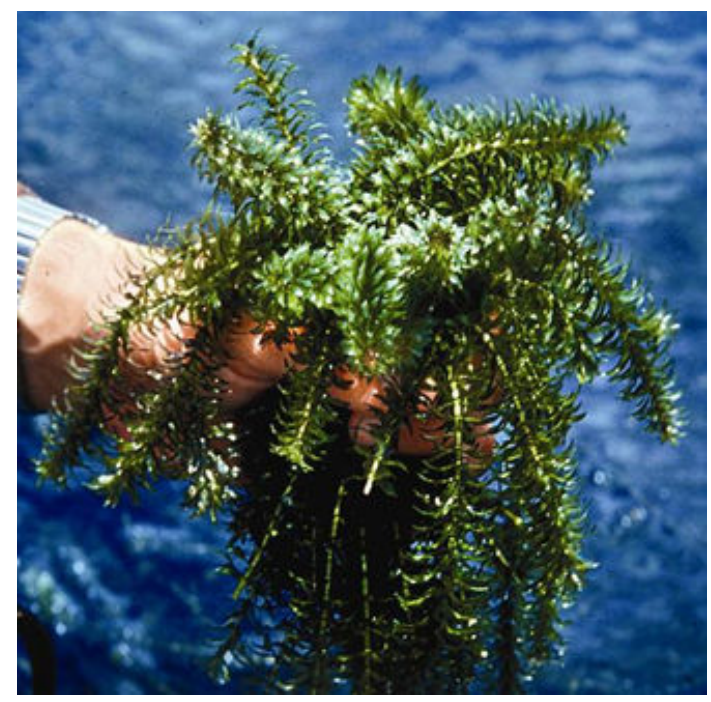

Figure 3. Hydrilla. Photo courtesy William Haller.

Chinese grass carp (Ctenopharyngodon idella Val.) [15, 16], but the vast majority of resource managers rely on chemical control to keep the growth of hydrilla in check.

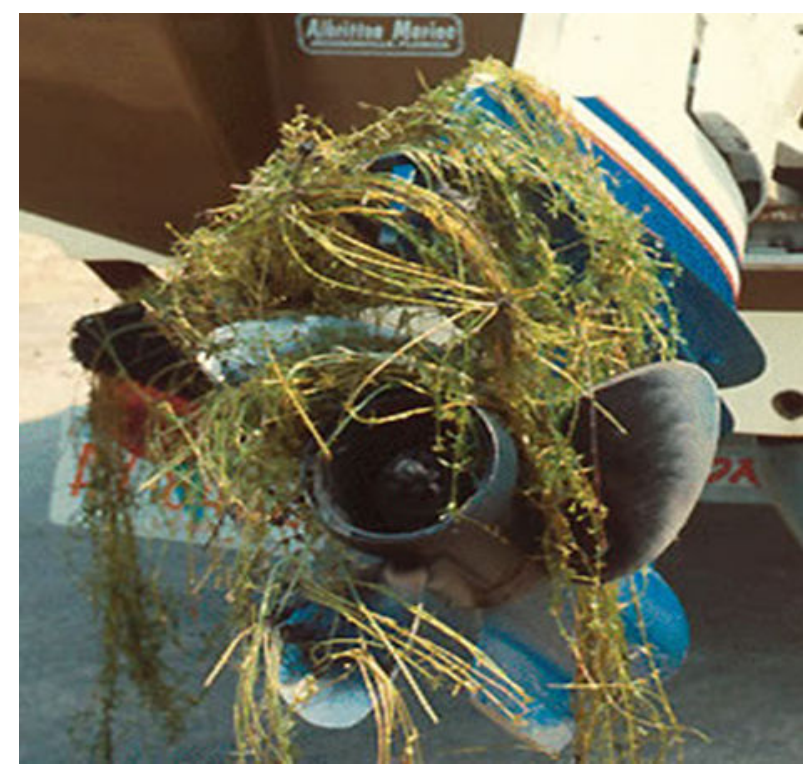

Figure 4. Boat motor clogged with hydrilla. Photo courtesy UF/IFAS Center for Aquatic and Invasive Plants. 
Waterhyacinth and hydrilla quickly establish and become invasive in virtually all areas where they have been introduced, but these species are not the only aquatic plants that cause problems in natural systems, reservoirs, and canals through the world. For example, resource managers charged with protecting the waters of the Pacific Northwest and many other parts of the US struggle with invasions of Eurasian watermilfoil (Myriophyllum spicatum L.), flowering rush (Butomus umbellatus L.), and curlyleaf pondweed (Potamogeton crispus L.) (Fig. 5). It is thought that these species were initially introduced through the aquarium and nursery trade, but have since spread throughout the country's waters as a result of improper or inadequate cleaning of contaminated equipment that has been moved from infested sites to pristine waters.
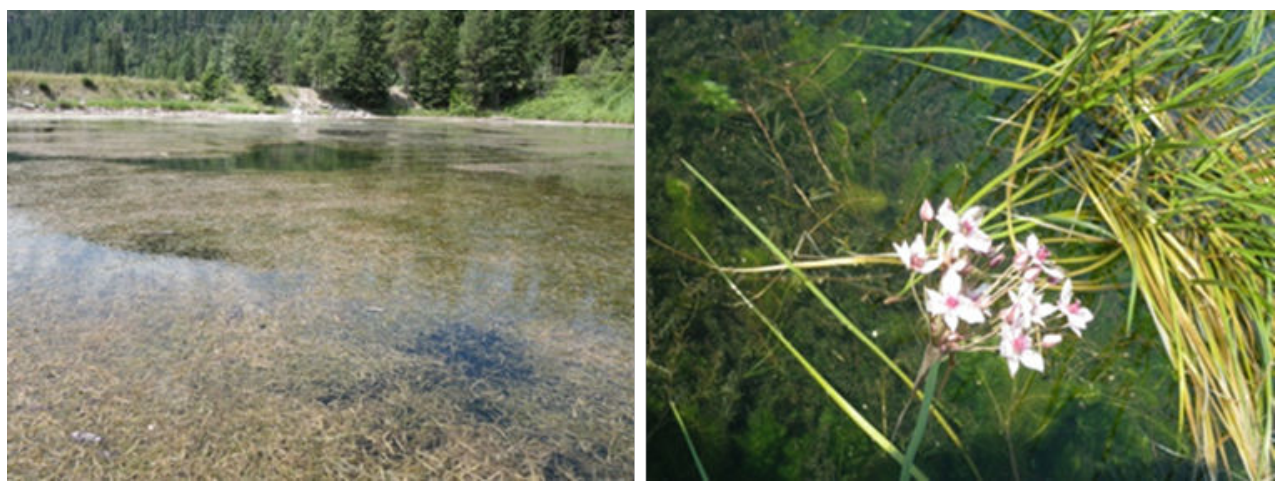

Figure 5. Other common aquatic invaders in the US. Left: curlyleaf pondweed. Right: flowering rush (emerged) and Eurasian watermilfoil (submersed). Photos courtesy Lyn Gettys.

It is clear that aquatic weeds can severely reduce ecosystem functions and limit the use of infested waters for anthropogenic activities such as recreation and flood control. However, invasive aquatic plants can pose serious risks to human health as well. For example, a number of floating species provide ideal conditions for mosquito breeding activities. Even in fastflowing water, the stagnant water needed for mosquito reproduction is often present in the rosettes of floating weeds such as waterhyacinth and waterlettuce (Pistia stratiotes L.) [17-19] (Fig. 6).

\section{Weed control methods in aquatic systems}

A number of techniques can be employed to control or reduce populations of aquatic weeds. Clearly, the most effective way to avoid the problems associated with invasive plants is through exclusion, or preventing them from entering uninfested aquatic systems. Public education programs that emphasize proper disposal of cultivated introduced plants and animals can be helpful, but target audiences (i.e., pet and aquarium owners) often remain unaware of the ecological consequences associated with the release of these organisms into 


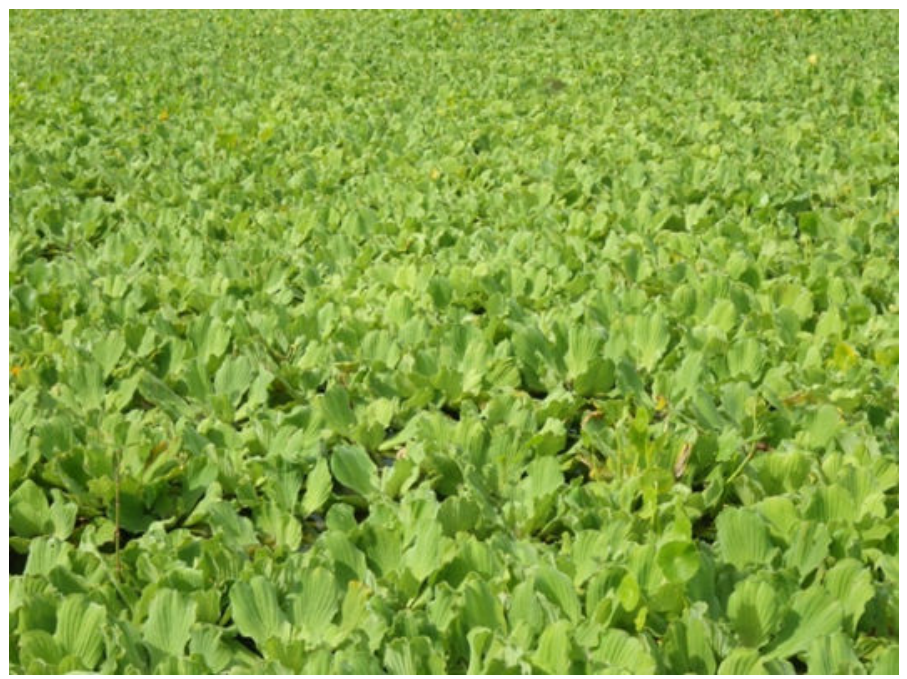

Figure 6. Waterlettuce. Photo courtesy Lyn Gettys.

public waters. Although this sort of intentional release is certainly a vector for the introduction of new invaders (see Section 2 of this chapter describing the introduction of waterhyacinth), accidental transfer of aquatic weeds frequently occurs when boats, trailers, and other equipment is moved from an invaded site to a pristine body of water (Fig. 7). The likelihood of introduction via this route can be reduced by requiring careful inspection of any object before movement from one body of water to another. This is especially important when boats and other equipment are being relocated from a body of water that is suspected of or known to harbor invasive species to one that is pristine. These inspections can identify seeds, vegetative fragments, larvae, veligers, and other propagules of invasive aquatic species and ensure their removal before launching at a new site, thus preventing the introduction of exotic organisms into an uninfested body of water. This method has been employed with some success in the northern US, where rigorous boat inspection programs have kept invasive aquatic plants and animals such as zebra and quagga mussels (Dreissena polymorpha and D. rostriformis bugensis, respectively) from spreading to new sites [20,21].

When exclusion programs fail and an exotic plant species colonizes a new system, managers often attempt to manually remove the invader as a first line of defense. The methods employed for removal efforts vary and are often dependent on available resources. For example, handpulling of target weeds may be effective, especially if the infestation is small and localized, and may be cost-effective if a pool of engaged stakeholders and volunteers can be mobilized to accomplish the task. If the new invader has colonized a relatively large area or has established in water deeper than 1 meter, the use of specialized equipment such as mechanical harvesters (Fig. 8) may be employed. Mechanical removal of aquatic weeds is often viewed by the public as the most "environmentally friendly" control method, especially among clientele that dislike the use of pesticides, and the technique certainly has utility under some circum- 


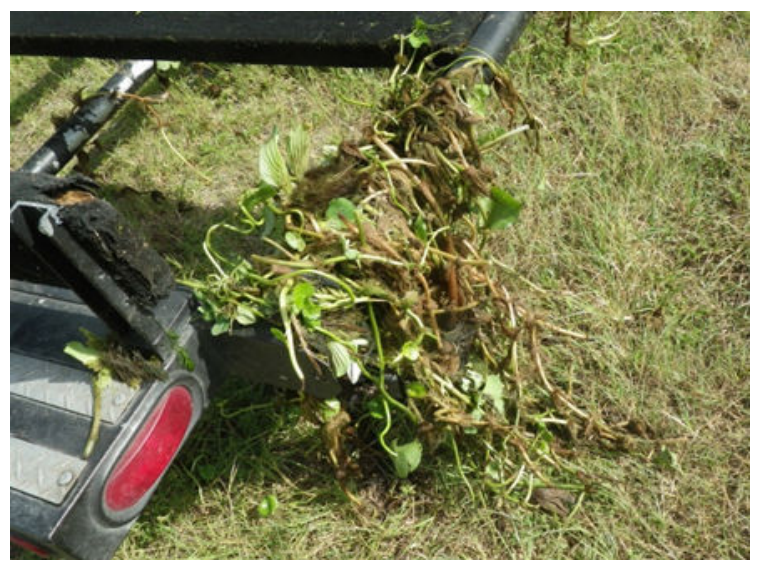

Figure 7. Aquatic weeds on a boat trailer. Photo courtesy Lyn Gettys.

stances. However, a number of factors must be taken into consideration before starting mechanical control efforts, regardless of whether volunteer labor or mechanical harvesters are employed. For example, it may be logistically difficult or prohibitively expensive to dispose of harvested plant material. Resource managers sometimes have access to a nearby "high and dry" site where collected weeds can be stockpiled and allowed to desiccate and decay, but harvested material must often be transported off-site for disposal. This process can add significantly to the cost of the project, especially if the weeds must be disposed of in a landfill that charges tipping fees. As much as $95 \%$ of the fresh weight of aquatic weeds is water; a single acre of hydrilla can weigh as much as 24,000 pounds $(10,886 \mathrm{~kg})$, but only 1,200 pounds $(544 \mathrm{~kg})$ of that weight is plant material and the remaining 22,800 pounds $(10,342 \mathrm{~kg})$ is water [22]. Also, removal of weeds by volunteers or mechanical harvesters typically causes fragmentation of plant material and fails to capture root crowns, tubers, seeds, and other propagules in the sediment. Many aquatic weeds - including hydrilla, curlyleaf pondweed, and Eurasian watermilfoil - easily root from fragments and quickly regrow from sediment- borne propagules. As a result, initial observations at many sites that are managed using hand or mechanical removal of aquatic weeds may suggest that these methods have successfully addressed the problem, but control of the new invader is often ephemeral and weed populations regenerate in as little as a few weeks. A third factor to consider when hand-pulling or using mechanical harvesters to remove aquatic weeds is water depth. Volunteers are unlikely to be able to remove plants growing in water that is deeper than 3 feet $(1 \mathrm{~m})$ without diving gear and most traditional mechanical harvesters can only remove plant material in the upper 5 feet $(1.5 \mathrm{~m})$ of the water column, although newer equipment can harvest weeds in the upper 10 feet $(3 \mathrm{~m})$ of water. These factors should be considered before launching a weed removal program, regardless of whether weeds are taken out of the system by hand or by utilizing mechanical harvesters, but there are additional challenges inherent to each method. For example, volunteers tasked with hand-pulling invaders must be adequately trained to ensure that they will be able to successfully identify the target weed, especially when the invader is 
similar in appearance to desirable native plants that should be allowed to remain in the system. In contrast, mechanical harvesters are "non-selective" - they indiscriminately remove all plant material in the harvesting zone and are unable to distinguish between weeds and native species. Also, mechanical harvesters often result in bycatch, or the removal of fish and other aquatic fauna along with plant material. This problem is most pronounced when shallowwater (upper 5 feet; $1.5 \mathrm{~m}$ ) harvesters are employed and can result in the removal of up to 28,000 fish per acre [23], but bycatch can be reduced by greater than $99 \%$ (removal of around 120 fish per acre) when deep-water (upper 10 feet; $3 \mathrm{~m}$ ) harvesting is utilized [24].

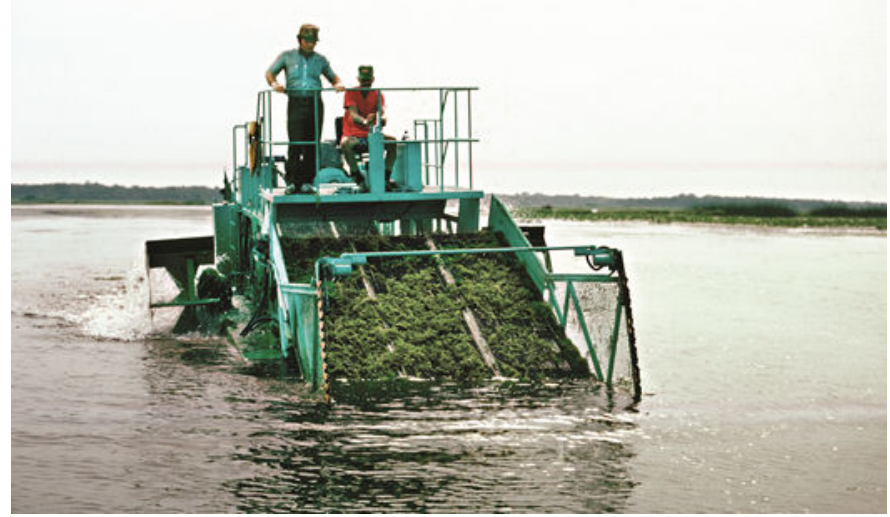

Figure 8. Mechanical harvesting of hydrilla. Photo courtesy William Haller.

Another method that can provide some control of unwanted aquatic species is biological control, or the use of organisms to reduce weed populations. This technique, often referred to as biocontrol, is based on the concept that most species that become weedy after introduction to a new region are not problematic in their native range due to the presence of endemic predators that keep their growth in check. Identifying and evaluating potential biocontrol agents is an arduous, time-consuming, expensive process. The process typically begins with researchers travelling to the invader's center of origin and collecting insects, pathogens, or other organisms that are found in association with the target weed species. These biological agents are quarantined and subjected to a battery of tests to determine whether they fit the criteria and requirements of successful biocontrol agents. A hallmark of a biocontrol agent is host specificity; in other words, they must cause damage exclusively to the target weed species while leaving other plants untouched $[25,26]$. Biocontrol agents should also be able to survive, grow, and reproduce in the invaded range of the weed and ideally, they should be able to form self-sustaining populations without augmentation. Some success has been realized using biocontrol organisms for aquatic weed control; for example, the Asian or Chinese grass carp (Ctenopharyngodon idella Val.) (Fig. 9) is well-known as a voracious consumer of hydrilla [27]. Unfortunately, grass carp are somewhat non-selective; although they are most frequently employed to control hydrilla, they will consume and eliminate virtually all submersed 
vegetation in an aquatic system. Also, because the grass carp is a non-native introduced species, special precautions must be taken to reduce the likelihood of these biocontrol agents becoming invasive themselves. In Florida and many other states in the US, a permit must be issued by state resource managers before the introduction of grass carp into an aquatic system (although some states prohibit the use of grass carp as biocontrol agents altogether) [28]. In most cases, permit holders must ensure that stocked waters are secured (i.e., water intakes and outflows must be screened) to prevent the fish from escaping into other waters and all released grass carp must be triploid. Triploidy is the presence of an additional set of chromosomes, a condition that is induced by subjecting fish eggs to cold, heat, or pressure shock treatments immediately after artificial fertilization, and renders the grass carp unable to reproduce [29].

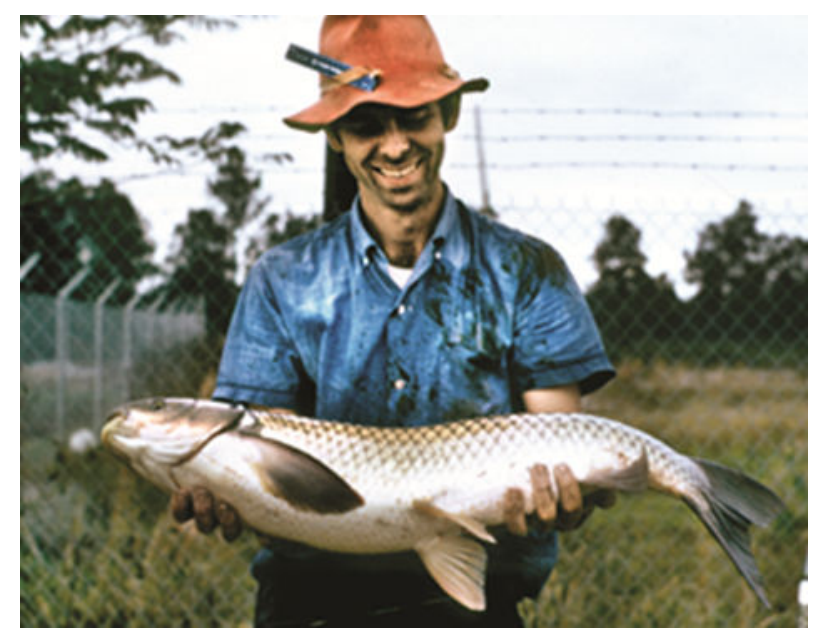

Figure 9. Asian grass carp. Photo courtesy William Haller.

Other organisms have also been employed as biocontrol agents. For example, a number of insects and pathogens have been evaluated for control of various aquatic weeds, including the noxious aquatic invader alligatorweed [Alternanthera philoxeroides (Mart.) Griseb.]. The most promising of these agents, the alligatorweed flea beetle (Agasicles hygrophila Selman and Vogt) (Fig. 10), can reduce populations to the point that more aggressive weed control methods can be reduced or even eliminated, provided winter temperatures in the region are mild enough to allow overwintering of the beetles [30]. Although these and other biocontrol agents have some utility in aquatic weed control, they cannot be relied on to completely eliminate infestations of invasive weeds. True biocontrol agents are host-specific; therefore, populations of the target weed must always be present in order to serve as a host or food source for the agent. As a result, weedy species cannot be eradicated through the actions of a biocontrol agent. When more complete control of aquatic weeds is necessary, resource managers rely heavily on chemical control, or the use of herbicides. 


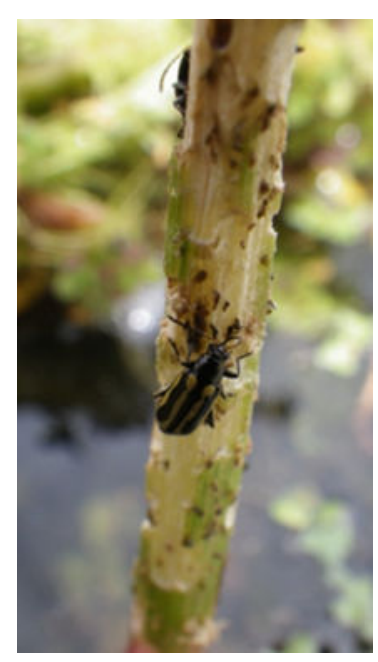

Figure 10. Alligatorweed flea beetle. Photo courtesy Lyn Gettys.

\section{Water use and its influence on herbicide selection}

A number of factors must be taken into consideration when selecting a herbicide for chemical control. Clearly, the most important criterion is efficacy of the product on the target weed. However, resource managers must also take into account how treated waters will be used. Although some aquatic systems are used for fisheries or crop production (e.g., rice cultivation), most are not used to grow food. Non-production waters targeted for aquatic weed control efforts can be categorized in a number of different ways, but the most common broad groupings include agricultural waters, flood control canals, recreational waters, retention ponds, and "development" waters (man-made lakes and ponds created for aesthetic reasons). Many waters are multi-use and span several of these categories, but this discussion will focus on the primary purpose of each grouping.

Agricultural waters are typically used for crop irrigation and for watering of livestock. A number of herbicides labeled for use in aquatic systems have irrigation and/or livestock watering restrictions. These restrictions preclude the use of treated water for a specific period of time or until the concentration of the herbicide is below a specified level. These restrictions vary among products and may also vary among products with the same active ingredient. Irrigation and livestock watering restrictions are clearly listed on the product label; compliance may be as simple as not using treated water for the appropriate length of time or may require laboratory tests to determine the concentration of herbicide in the water. Intentional or accidental failure to adhere to irrigation restrictions may result in a number of consequences, including - but not limited to - damage to livestock and non-target crop plants, herbicide residues in crops that exceed the allowed tolerance established by the United States Environ- 
mental Protection Agency (USEPA), and prosecution by the USEPA for failure to follow label guidelines.

Flood control canals should be able to quickly move large volumes of water. These systems may be used only rarely for their true purpose; however, their ability to function as intended is critical when residential or developed areas are threatened by tropical storms, hurricanes or other extreme weather events. As such, it is critical that these canals be kept clear of aquatic vegetation that may impede the flow of water. A "scorched earth" philosophy and the use of a non-selective herbicide is sometimes employed to ensure that flood control canals remain free of aquatic weeds, and native plants are not exempt from weed control efforts in these systems. This is because even a small population of submersed plants - be it a weed such as hydrilla or a native plant such as eelgrass (Vallisneria americana Michx.) (Fig. 11) - can severely restrict water flow and increase the likelihood of flooding. Although the goal of weed control efforts in flood control canals is often to eliminate as much vegetation in the water column and surface as possible, canal banks should remain vegetated (ideally with a well-rooted, noninvasive native species) to prevent erosion during periods of rapid flow.

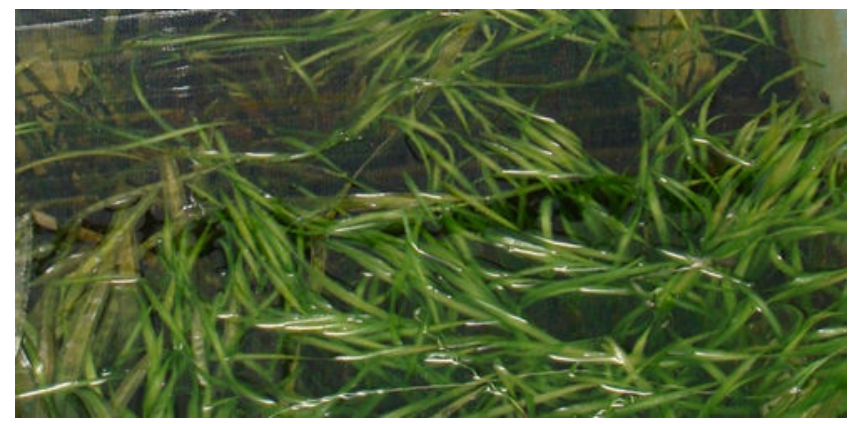

Figure 11. Eelgrass. Photo courtesy Lyn Gettys.

Recreational waters are typically managed to facilitate anthropogenic activities such as fishing, duck hunting, boating, and swimming. As a result, stakeholders - along with expectations and concerns - are many and varied. For example, most research has shown that sport fish populations in natural areas are greatest when submersed plants inhabit $30-40 \%$ or less of the water column [31, 32], but many sportfishers believe that dense weeds are necessary to provide good habitat for sportfish such as largemouth bass [33-35]. Also, some aquatic plants - including native species such as pondweed (Potamogeton spp.) and invasive weeds such as hydrilla - are eaten by ducks and waterfowl (Fig. 12). In fact, many duck hunters (and some waterfowl scientists) are less than supportive of aquatic vegetation control operations because they say these efforts deplete duck and waterfowl feeding habitat [36, 37]. These and other stakeholders often protest when weed control efforts are undertaken because they suspect reductions in weed coverage will negatively impact their hunting and fishing activities. Although some sportsmen recognize that it is rarely possible to maintain low coverage rates of aquatic weeds, many others fail to appreciate that the unchecked growth characteristic of 
submersed weeds necessitates weed control efforts that focus on eliminating as much vegetation as possible.

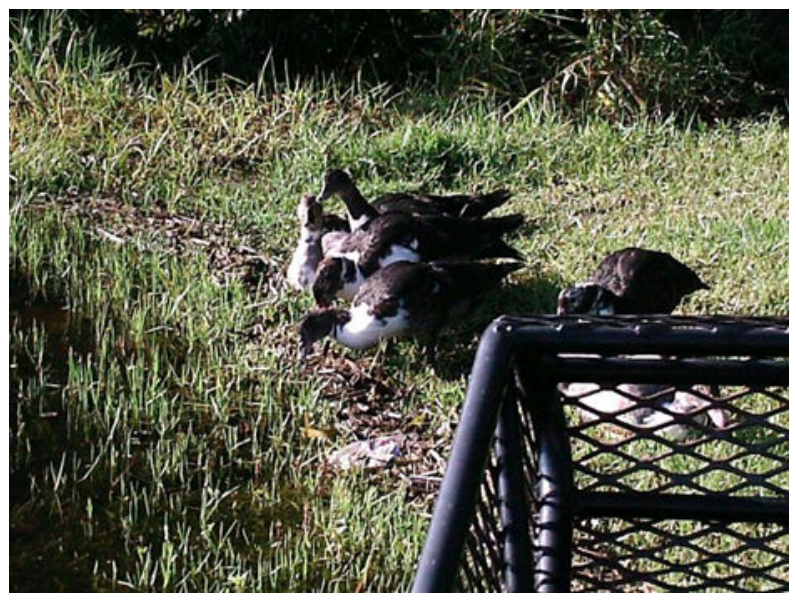

Figure 12. Ducks consuming seeds and vegetation on a pond bank. Photo courtesy Lyn Gettys.

Other recreational activities - such as boating and the use of personal watercrafts such as jet skis - are also directly impacted by aquatic weeds. Access to boat ramps can be restricted by overabundant growth of macrophytes in and around the littoral zone, while dense submersed vegetation can wrap around the propellers of outboard motors and hinder or halt boat operation. In addition, dense submersed vegetation can make swimming and waterskiing difficult, dangerous, or nearly impossible, and can increase the risk of drowning if individuals become entangled in dense weeds.

Retention ponds are by definition designed to be ephemeral; their ultimate purpose is to retain storm water, capture runoff, filter nutrients, and lessen or prevent flooding. Nevertheless, many stakeholders consider retention ponds to be long-term "water features" that enhance the aesthetics of urban and suburban areas. Retention ponds may be used on a limited basis for recreational purposes (e.g., fishing and swimming), but these activities are often restricted by the resource owner to limit liability. Aquatic weed control efforts in retention ponds must take into account stakeholder expectations; for example, if the goal is to reduce or eliminate unsightly algae or submersed weeds while leaving a fringe of ornamental flowering plants in the littoral zone, care must be taken to choose a selective herbicide that will control the target species without causing unacceptable levels of damage to desirable vegetation. Weed control efforts in retention ponds may also be challenging for resource managers due to the high visibility of these sites. Many stakeholders become alarmed at the sight of herbicide applicators wearing "moon suits" (Fig. 13) - a common name for personal protective equipment specified on the herbicide label - and assume that the water is being poisoned. Therefore, it can be useful to ensure that applicators are able to communicate with the public and to assuage fears regarding the toxicity of herbicides labeled for use in aquatic systems. 


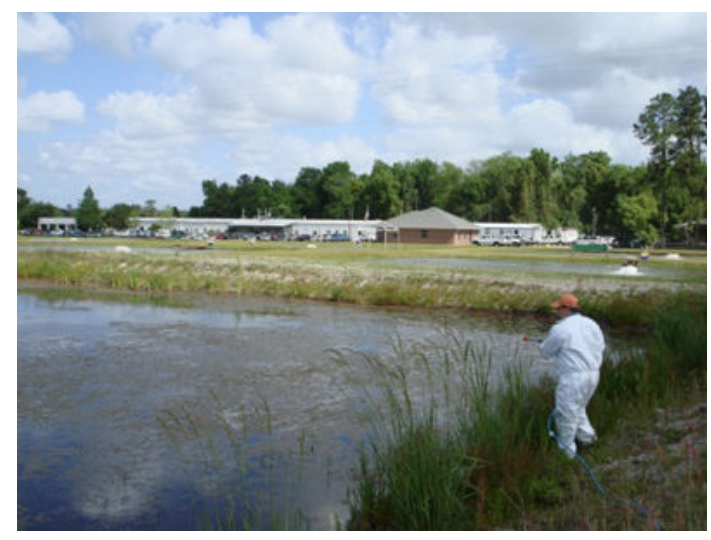

Figure 13. Herbicide applicator wearing personal protective equipment. Photo courtesy Lyn Gettys.

"Development" waters are man-made lakes and ponds that are created with the primary goal of increased aesthetics. These artificial bodies of water provide residential developers with a source of fill dirt, after which they are able to market adjacent homesites as desirable waterfront property, which are often sold at a premium. They also increase the value of the entire development, which can now be advertised as including ponds and water features. Some development waters are maintained in a pristine, plant-free state and rely on fountains or other hardscape features to provide an attractive visage. Others are planted or aquascaped, either to simulate natural bodies of water or to mimic large-scale water gardens with showy ornamental plants (Fig. 14). Because development waters are rarely connected to public waters, weed problems in these systems are typically the result of introduction by humans, or less often, by waterfowl and wildlife that have visited the development waters after spending time in nearby weed-infested aquatic systems. Anthropogenic introduction of aquatic weeds is frequently intentional, as when property owners dump unwanted aquarium or water garden plants into the development waters. However, the introduction of aquatic weeds can occur inadvertently when invasive species are misidentified and sold as desirable native plants or when propagules of invasive species "hitchhike" as contaminants on the desirable plants that are used for aquascaping [38-40]. Because development waters are considered valuable components of the landscape, they are often intensively managed to ensure that their aesthetic qualities are optimized.

\section{Herbicide usage and labeling in aquatic systems - Case studies from Florida (USA)}

Herbicides are used extensively to control weeds in crop production and agricultural systems. The terrestrial agrichemical industry in the US is robust; estimated sales in 2007 were $\$ 12.454$ billion, with $40 \%$ of the market ( $\$ 5.856$ billion) attributable to herbicides [41]. In contrast, the 


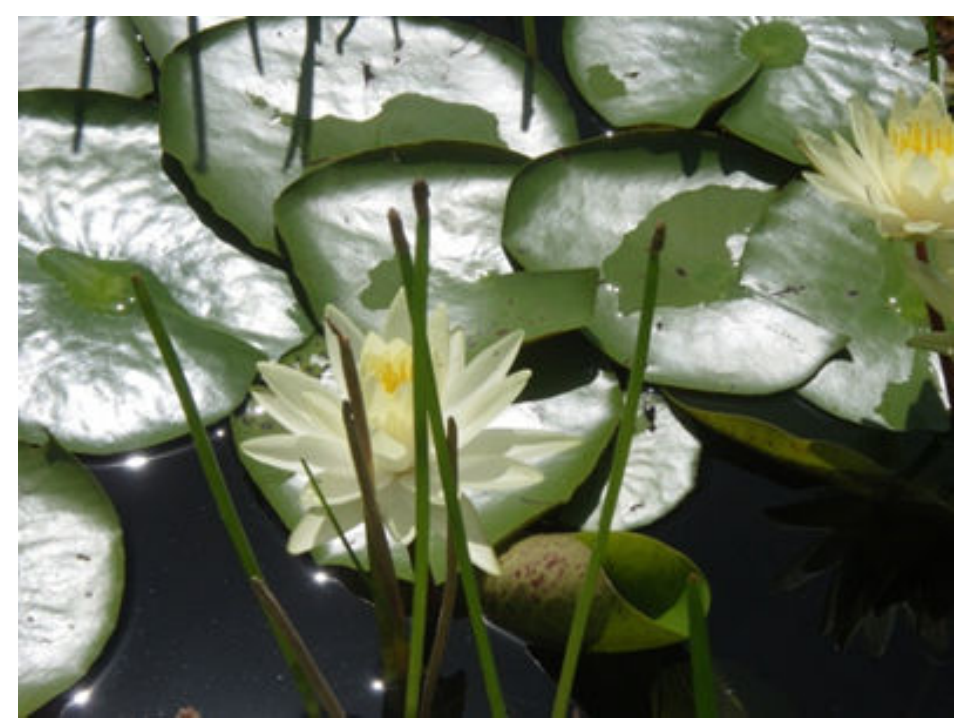

Figure 14. Waterlilies in a development pond. Photo courtesy Lyn Gettys.

market for aquatic weed control products is much smaller; for example, public agencies in Florida spent around \$22.5 million in 2005 to manage aquatic invaders in public waters [42]. Any product that is marketed in the US to control pests - including weeds - must first be labeled by the US Environmental Protection Agency (USEPA or the Agency). Obtaining a pesticide label from the USEPA is a time-consuming and expensive undertaking; the Agency requires registrants (the manufacturer or group seeking a pesticide label) to submit data from more than 100 tests before a product can be evaluated for possible labeling, and the testing process typically requires the investment of tens of millions of dollars [43]. These tests are conducted to determine the effects of the experimental pesticide on the organism targeted for control, but also to assess its impact on non-target organisms, human health, and the environment as well. USEPA regulation of pesticides began with the adoption of the Federal Insecticide, Fungicide, and Rodenticide Act (FIFRA) in 1947; FIFRA has since been amended multiple times, most notably by the Federal Environmental Pesticide Control Act of 1972, and continues to serve as the primary process to ensure that human health and the environment are not negatively impacted by the use of pesticides [43].

Because obtaining a pesticide label from the USEPA requires significant financial resources, registrants only request Agency evaluation of products that are likely to capture a market large enough to offset the costs associated with obtaining a pesticide label. As outlined above, aquatic herbicides constitute a small niche market, with limited potential to allow registrants to recoup the funds required for initial labeling of a pesticide. Therefore, most herbicides that are labeled by the USEPA for use in aquatic systems have already been approved by the Agency for terrestrial use. Small-scale testing - such as greenhouse studies evaluating the efficacy of a product on aquatic weeds - may be conducted on a limited basis under specific conditions 
(Fig. 15). If these preliminary experiments suggest that a herbicide shows promise as an aquatic weed control agent, the registrant may pursue an aquatic label for the product. Registrants seeking an aquatic label must submit additional data to the Agency, including how the product affects target and non-target aquatic flora and fauna, its persistence in aquatic sediments and water, and the nature and impacts of its decomposition components. These tests are conducted under Experimental Use Permits (EUPs) issued by the USEPA and by state regulatory agencies. For example, the testing of pesticides in Florida waters is conducted under EUPs issued by the USEPA and by the Florida Department of Agriculture and Consumer Services (FDACS). There are a number of restrictions on waters that are treated with experimental products; for example, treated waters may not be used for fishing, swimming, irrigation, drinking, or watering of livestock. Evaluation of an EUP herbicide typically continues for several years until the registrant has sufficient data to submit to the USEPA, along with a proposed aquatic label [43]. The aquatic label includes all of the information found on terrestrial labels, such as the personal protective equipment that is required to handle and apply the herbicide. In addition, aquatic herbicide labels include water use restrictions to prevent harm to human health and the environment. Some products have no limitations on the use of treated waters; however, others may specify that water from the system may be not be used for various purposes until either a certain period of time has elapsed or until the concentration of the herbicide falls below a specified set point.

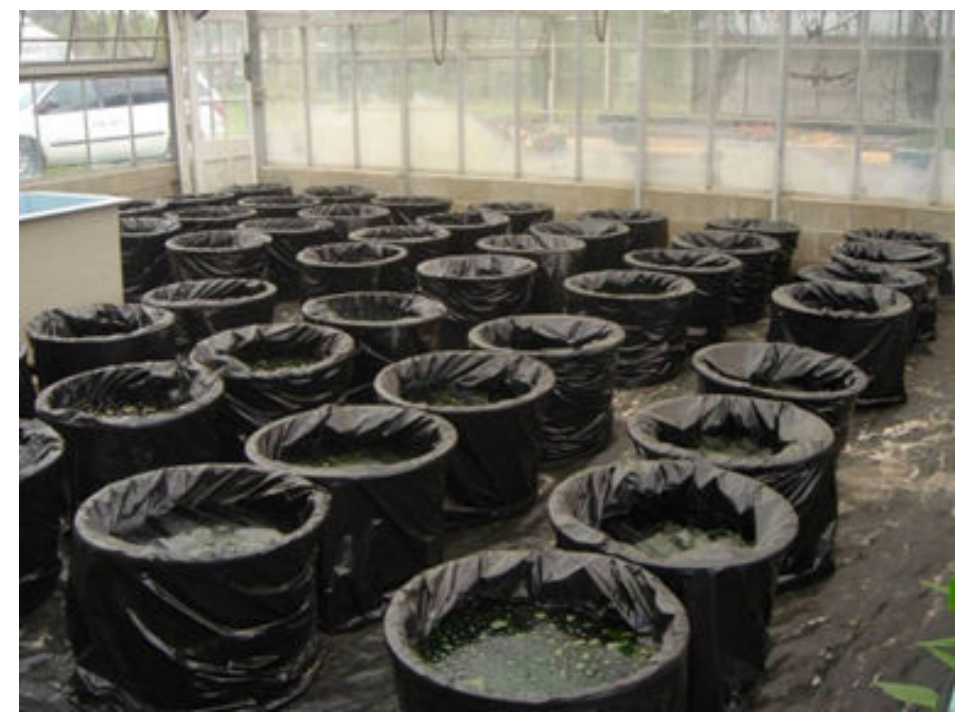

Figure 15. Efficacy testing in the greenhouse. Photo courtesy William Haller.

It is important to note that all herbicides labeled for aquatic weed control by the USEPA in the US are "general use" pesticides that can be purchased and applied by anyone, including homeowners and unlicensed applicators. However, the USEPA allows states to apply addi- 
tional restrictions to pesticides; in fact, a number of states classify aquatic herbicides as "restricted use" products that can only be purchased and applied by individuals that have received a state-issued license. Any and all individuals using a pesticide must comply with all of the requirements outlined on the pesticide label. The label is a legally binding document and misuse of a pesticide can result in serious consequences, up to and including the levy of fines and incarceration [43]. Although licensing is not required by federal law to purchase or apply aquatic herbicides, the vast majority of public agencies and private companies that employ applicators to manage aquatic systems specify that all personnel using these products obtain an aquatic pesticide applicator license from the state in which they are employed. This ensures that applicators have been trained and have shown competency in a number of important areas, including label interpretation, proper application techniques, equipment calibration, use of personal protective equipment, and proper disposal methods. Each state has its own requirements for obtaining and keeping a pesticide license. For example, all certified pesticide applicators in Florida must pass at least two written examinations - one that tests core competency and one that evaluates competence in a specific area or category [44]. A number of categories are offered to individuals seeking certification in Florida, and applicators may become licensed in as many categories as desired after the core competency examination has been successfully completed. Most licensees that are charged with applying pesticides in aquatic systems have multiple category certifications, the most common being aquatics, natural areas, and right-of-way. Florida pesticide applicator licenses are valid for four years from the date of issuance, and a license can be renewed in one of two ways. Applicators may submit proof that they have attended training sessions and earned a specified number of continuing education units (CEUs) in core and category areas during the four-year period since the license was issued or last renewed. Alternatively, applicators may re-take core competency and category examinations every four years [44].

\section{How environmental factors influence herbicide applications}

Herbicide applications to the aquatic environment share some of the challenges associated with treatment of agricultural lands, including drift (the unintended aerial dispersal of herbicides from the treatment area) and damage to desirable non-target plants. However, aquatic herbicide applications are further complicated by a number of factors unique to aquatic systems. For example, herbicides used for weed control in crop production typically reach the target plant at the concentration in which they are applied. In contrast, products employed to control submersed aquatic weeds must travel through the water column to reach their target and thus undergo substantial dilution before coming into contact with the plant. In addition, flow and currents result in the movement of the herbicide out of the treated area, which reduces contact exposure time (the period in which the product maintains contact with the target weed) and further limits efficacy of the treatment [45]. Another factor that complicates herbicide application in aquatic systems is the stratification of waters (Fig. 16), especially within systems in temperate regions. Most bodies of water have three distinct zones or layers, with little mixing among the layers. The upper and lower portions of a body of water are referred to as the 
epilimnion and hypolimnion, respectively. Water in the epilimnion is directly exposed to ambient air temperatures and therefore tends to be very warm in the summer and cold or frozen during winter. In contrast, water in the hypolimnion maintains a more or less constant temperature all year. The epilimnion and hypolimnion are separated by the thermocline, a layer characterized by drastic temperature changes $[45,46]$. The effect of stratification may have little effect on efforts to manage emergent or floating aquatic weeds. However, this phenomenon can have a substantial effect on treatment of submersed invaders, because herbicides applied to the epilimnion are unlikely to penetrate through the thermocline to reach target weeds growing in the hypolimnion.

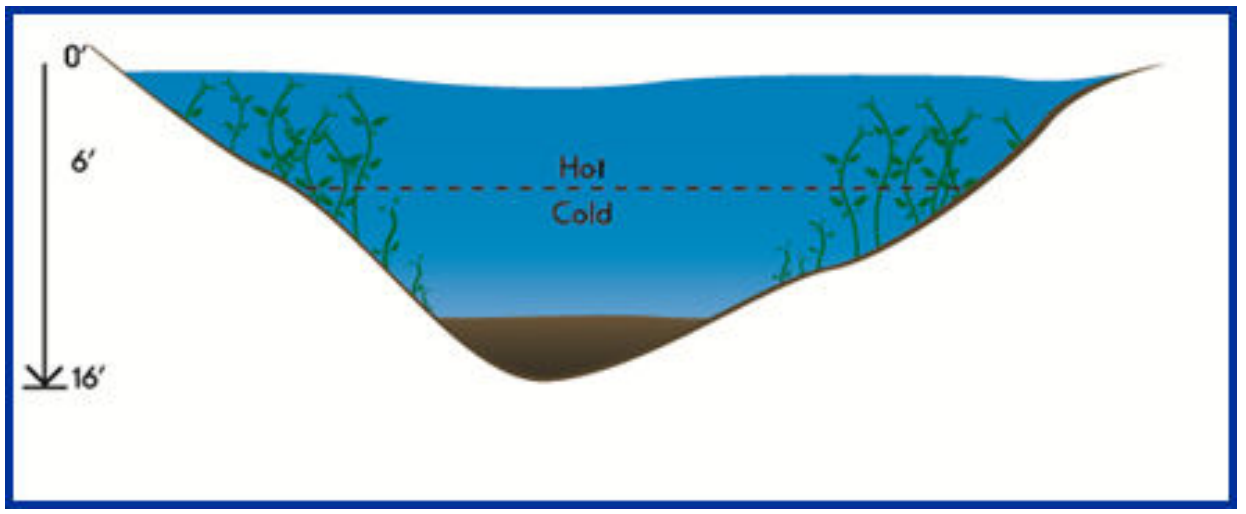

Figure 16. Stratified lake (summer, with warm epilimnion). Illustration courtesy UF/IFAS Center for Aquatic and Invasive Plants.

Another important consideration in the treatment of aquatic systems is the effect of weed control activities on fish that reside in waters targeted for herbicide application. Although the presence of fish does not affect herbicide efficacy, special precautions must be taken to ensure that these and other aquatic denizens are not harmed as a result of weed control efforts. Only a few herbicides labeled for use in bodies of water are inherently dangerous to fish, but fish kills are nonetheless a major concern for applicators working in aquatic systems. The primary reason fish kills occur after weed control activities are undertaken is a reduction in dissolved oxygen (DO), which results from a number of factors [47]. Primary among these factors is the decomposition of vegetative material that has been killed by herbicides and is broken down by aerobic organisms, which deplete DO during the process. Also, photosynthesis by plants that have been killed by herbicides is eliminated and the DO they previously contributed to the water column is no longer produced, further reducing levels of DO. In order to reduce the likelihood of fish kills, most labels for aquatic products specify that herbicides be applied to only a portion of a weed-infested body of water at a time to allow fish to escape from treated areas and to prevent the extreme drop in DO that accompanies the elimination of all vegetation from an aquatic system. 


\section{Application methods in aquatic systems}

Some of the techniques for applying herbicides in aquatic systems are similar to those used for weed control in crop production. This is especially true when the target aquatic invaders are growing along ditchbanks or shorelines or in narrow canals that can be treated using a backpack sprayer or a truck, tractor or other wheeled vehicle. However, herbicide applications to open waters require specialized equipment and tools in order to effectively reach the aquatic weeds that are targeted for control, and the primary vehicle required for aquatic weed control is a boat. The size and disposition of the treatment boat varies and is dependent on the application method to be employed, which is often dictated by the target weed and the form of herbicide being utilized. Aquatic herbicides are typically sold in liquid and granular formulations, and some active ingredients are available in both forms [48]. Granular formulations are most often applied using a boat-mounted spreader (Fig. 17). Most liquid formulations are packaged as concentrates and are applied in dilute form. Dilution is frequently accomplished by adding the concentrate to a boat-mounted tank filled with water. A variety of equipment exists to apply herbicides that have been diluted in an onboard tank; these include handguns (for treating emergent and floating weeds), booms (for treatment of surface water), and trailing weighted hoses (for subsurface treatments) [45, 49]. Regardless of the formulation and application method employed, calibration of application equipment is critically important to ensure that the correct amount of herbicide is introduced to the system. Poorly calibrated equipment may result in the application of too little herbicide, which will likely yield poor weed control and reduced product efficacy. Using an excess amount of herbicide will increase costs associated with the treatment and may result in concentrations above those specified on the product label; as outlined above, this is a violation of federal law and may have serious legal consequences.

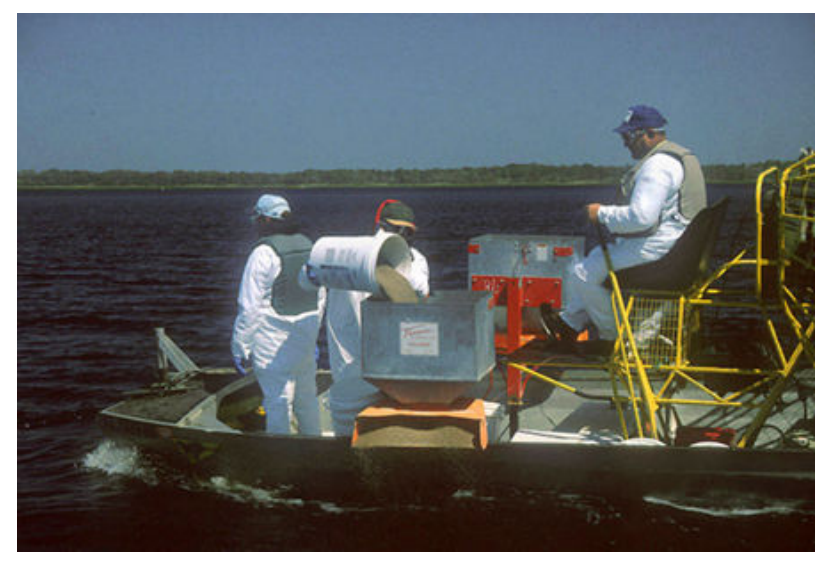

Figure 17. Application of granular herbicide using a boat-mounted spreader. Photo courtesy UF/IFAS Center for Aquatic and Invasive Plants. 


\section{Conclusions}

Fresh-water resources are extremely important components of global and local ecosystems. The introduction of exotic invasive species to these systems limits their ability to function as healthy, diverse habitats for native flora and fauna; in addition, anthropogenic uses such as flood control, public safety, and recreation are hindered as well. The most effective method to reduce the impact of aquatic invaders is to prevent their introduction to these valuable and important systems, but invasive species continue to become established in aquatic systems throughout the world. The primary method used to control introduced aquatic weeds in the US is the application of registered aquatic herbicides. Pesticides that are applied to waters in the US are labeled and registered by the USEPA after extensive testing, and most states including Florida - require that the use of these products be regulated by state agencies as well. Aquatic herbicides represent a small subset of the pesticides labeled by the USEPA and registrants only pursue aquatic labeling of products if there is a market large enough to offset the costs associated with additional registration requirements. A number of unique challenges are associated with weed control in aquatic systems, including the effects of dilution, current, and stratification of water within systems. These challenges can be overcome through the selection of proper herbicides and application methods.

\section{Acknowledgements}

This publication is a contribution of the University of Florida Institute for Food and Agricultural Sciences and the Florida Agricultural Experiment Station.

\section{Author details}

Lyn A. Gettys ${ }^{1^{*}}$, William T. Haller ${ }^{2^{*}}$ and Gregory E. MacDonald ${ }^{3^{*}}$

*Address all correspondence to: lgettys@ufl.edu

*Address all correspondence to: whaller@ufl.edu

*Address all correspondence to: pineacre@ufl.edu

1 University of Florida Institute of Food and Agricultural Sciences, Department of Agronomy, Fort Lauderdale Research and Education Center, Davie, FL, USA

2 University of Florida Institute of Food and Agricultural Sciences, Department of Agronomy, Center for Aquatic and Invasive Plants, Gainesville, FL, USA

3 University of Florida Institute of Food and Agricultural Sciences, Department of Agronomy, Gainesville, FL, USA 


\section{References}

[1] Klorer J. 1909. The water hyacinth problem. Journal of the Association of Engineering Societies 42:33-48.

[2] Webber HJ. 1897. The water hyacinth, and its relation to navigation in Florida. United States Department of Agriculture, Division of Botany. Bulletin No. 18. http:// ia600406.us.archive.org/9/items/waterhyacinthits00webb/waterhyacinthits00webb.pdf (accessed 22 August 2012).

[3] Penfound WT, Earle TT. 1948. The biology of the water hyacinth. Ecological Monographs 18(4):447-472. http://www.jstor.org/stable/1948585 (accessed 22 August 2012).

[4] Holm L, Doll J, Holm E, Pancho J, Herberger J. 1997. World weeds: natural histories and distribution. John Wiley, New York, USA.

[5] Lowe S, Browne M, Boudjelas S, De Poorter M. 2000. 100 of the world's worst invasive alien species: a selection from the global invasive species database. The Invasive Species Specialist Group. www.issg.org/booklet.pdf (accessed 22 August 2012).

[6] Langeland KA. 1996. Hydrilla verticillata (L.F.) Royle (Hydrocharitaceae), "The perfect aquatic weed". Castanea 61(3):293-304.

[7] McLane WM. 1969. The aquatic plant business in relation to infestations of exotic aquatic plants in Florida waters. Hyacinth Control Journal 8:48-49.

[8] Schmitz DC, Nelson BV, Nall LE, Schardt JD. 1991. Exotic aquatic plants in Florida: a historical perspective and review of present aquatic plant regulation program. In: Center TD, Doren RF, Hofstetter RL, Myers RL, Whiteaker LD (eds.). Proceedings of a symposium on exotic pest plants, pp. 303-336. November 2-4, 1988, Miami, Florida. United States Department of the Interior, National Park Service, Washington, DC, USA.

[9] Langeland KA, Sutton DL. 1980. Regrowth of hydrilla from axillary buds. Journal of Aquatic Plant Management 18:27-29.

[10] Glomski LM, Netherland MD. 2012. Does hydrilla grow an inch per day? Measuring short-term changes in shoot length to describe invasive potential. Journal of Aquatic Plant Management 50:54-57.

[11] Haller WT, Sutton DL. 1975. Community structure and competition between hydrilla and vallisneria. Hyacinth Control Journal 13:48-50.

[12] Madsen JD. 1997. Methods for management of nonindigenous aquatic plants. In: Luken JO, Thieret JW (eds.). Assessment and management of plant invasions, pp. 145-171. Springer: New York, USA. 
[13] Holland LE, Huston ML. 1984. Relationship of young-of-the-year northern pike to aquatic vegetation types in backwaters of the Upper Mississippi River. North American Journal of Fisheries Management 19:18-27.

[14] ENSR. 2005. Rapid response plan for hydrilla (Hydrilla verticillata) in Massachusetts. Massachusetts Department of Conservation and Recreation. Boston, Massachusetts, USA. http://www.mass.gov/dcr/watersupply/lakepond/downloads/rrp/hydrilla.pdf (accessed 23 August 2012).

[15] McGehee JT. 1979. Mechanical hydrilla control in Orange Lake, Florida. Journal of Aquatic Plant Management 17:58-61.

[16] Sutton DL, Vandiver VV. 2006. Grass carp: a fish for biological management of hydrilla and other aquatic weeds in Florida. Bulletin No. 867. Florida Cooperative Extension Service, Institute of Food and Agricultural Sciences, University of Florida. http://edis.ifas.ufl.edu/fa043 (accessed 23 August 2012).

[17] Lounibos LP, Escher RL. 1985. Mosquitoes associated with water lettuce (Pistia stratiotes) in southeastern Florida. Florida Entomologist 68(1):169-178.

[18] Mulrennan JA. 1962. The relationship of mosquito breeding to aquatic plant production. Hyacinth Control Journal 1:6-7.

[19] Seabrook EL. 1962. The correlation of mosquito breeding to hyacinth plants. Hyacinth Control Journal 1:18-19.

[20] Idaho Department of Agriculture, Aquatic Ecosystem Restoration Foundation, and Pacific States Marine Fisheries Commission. 2012. A review of the state of Idaho dreissenid mussel prevention and contingency plans. http://aquatics.org/musselreport.pdf (accessed 14 November 2012).

[21] McNabb TJ. 2012. Aquatic invasive species: spreading prevention activities. Aquatics 34(2):19-20.

[22] Zimba PV, Hopson MS, Smith JP, Colle DE, Shireman JV. 1995. Chemical composition and distribution of submersed aquatic vegetation in Lake Okeechobee, Florida (1989-1991). In: Aumen NG, Wetzel RG (eds.). Ecological studies on the littoral and pelagic systems of Lake Okeechobee, Florida (USA). Advances in Limnology 45:241-246.

[23] Haller WT, Shireman JV, DuRant DF. 1980. Fish harvest resulting from mechanical control of hydrilla. Transactions of the American Fisheries Society 109:517-520.

[24] Haller WT, Jones DK. 2012. Technology and improved efficacy of mechanical control of hydrilla. Aquatics 34(3):17-19.

[25] DeLoach CJ. 1997. Biological control of weeds in the United States and Canada. In: Luken JO, Thieret JW (eds.). Assessment and management of plant invasions, pp. 172-194. Springer: New York, USA. 
[26] Cuda JP, Charudattan R, Grodowitz MJ, Newman RM, Shearer JF, Tamayo ML, Villegas B. 2008. Recent advances in biological control of submersed aquatic weeds. Journal of Aquatic Plant Management 46:15-32.

[27] Haller WT. 1994. Probable grass carp stocking scenarios. In: Haller WT (ed.). Proceedings of the Grass Carp Symposium, pp. 236-238, 7-9 March 1994, Gainesville, Florida. US Army Engineer Waterways Experiment Station, Vicksburg, Mississippi, USA.

[28] Colle D. 2009. Grass carp for biocontrol of aquatic weeds. In: Gettys LA, Haller WT, Bellaud M. (eds.). Biology and control of aquatic plants: a best management practices handbook, pp. 61-64. Aquatic Ecosystem Restoration Foundation, Marietta, Georgia, USA.

[29] Cassani JR, Caton WE. 1986. Efficient production of triploid grass carp (Ctenopharyngodon idella) utilizing hydrostatic pressure. Aquaculture 55(1):43-50.

[30] Buckingham GR. 2002. Alligatorweed. In: Van Driesche R, Blossey B, Hoddle M, Lyon S, Reardon R (eds.). Biological control of invasive plants in the eastern United States, pp. 5-15. USDA Forest Service Publication FHTET-2002-04, 413 p.

[31] Canfield DE Jr., Hoyer MV. 1992. Aquatic macrophytes and their relationships to Florida lakes. Final report to the Bureau of Aquatic Plants, Florida Department of Natural Resources. Tallahassee, Florida, USA.

[32] Colle DE, Shireman JV. 1980. Coefficients of condition for largemouth bass, bluegill, and redear sunfish in hydrilla-infested lakes. Transactions of the American Fisheries Society 109:521-531.

[33] Estes JR, Sheaffer WA, Hall EP. 1990. Study I. Fisheries studies of the Orange Lake chain of lakes. Florida Game and Fresh Water Fish Commission. Tallahassee, Florida, USA.

[34] Porak WF, Crawford S, Renfro D, Cailteux RL, Chadwick J. 1990. Study XII. Largemouth bass population responses to aquatic plant management strategies. Florida Game and Fresh Water Fish Commission. Tallahassee, Florida, USA.

[35] Tucker T. 1987. How to fish hydrilla. Bassmaster 20(9):30-34.

[36] Johnson FA, Montalbano F III. 1987. Considering waterfowl habitat in hydrilla control policies. Wildlife Society Bulletin 15(3):466-469.

[37] Anonymous. 2011. Background information for the Fish and Wildlife Conservation Commission's position on hydrilla management. Florida Fish and Wildlife Conservation Commission, Tallahassee, Florida, USA. http://myfwc.com/media/1386747/ hydrilla-mgmt-position-background-information.pdf (accessed 31 October 2012).

[38] Les DH. 1996. Hydrilla verticillata threatens New England. Aquatic Exotic News 3(1):1-2. 
[39] Maki K, Galatowitsch S. 2004. Movement of invasive aquatic plants into Minnesota (USA) through horticultural trade. Biological Conservation 118(3):389-396.

[40] Keller RP, Lodge DM. 2007. Species invasions from commerce in live aquatic organisms: problems and possible solutions BioScience 57(5):428-436.

[41] US Environmental Protection Agency. 2011. Pesticides industry sales and usage: 2006 and 2007 market estimates. http://www.epa.gov/opp00001/pestsales/07pestsales/ market_estimates2007.pdf (accessed 19 November 2012).

[42] Mossler MA, Langeland KA. 2009. Florida crop/pest management profile: aquatic weeds. Document PI-138, Pesticide Information Office, Agronomy Department, Florida Cooperative Extension Service, Institute of Food and Agricultural Sciences, University of Florida http://edis.ifas.ufl.edu/pdffiles/PI/PI17500.pdf (accessed 19 November 2012).

[43] Layne C, Stubbs D. 2009. Requirements for registration of aquatic herbicides. In: Gettys LA, Haller WT, Bellaud M. (eds.). Biology and control of aquatic plants: a best management practices handbook, pp. 145-150. Aquatic Ecosystem Restoration Foundation, Marietta, Georgia, USA.

[44] Florida Department of Agriculture and Consumer Services. 2012. Pesticide applicator licenses. http://www.freshfromflorida.com/onestop/aes/pestapp.html (accessed 19 November 2012).

[45] Haller WT. 2009. Aquatic herbicide application methods. In: Gettys LA, Haller WT, Bellaud M. (eds.). Biology and control of aquatic plants: a best management practices handbook, pp. 151-156. Aquatic Ecosystem Restoration Foundation, Marietta, Georgia, USA.

[46] Mudge CR, Haller WT, Gettys LA. 2011. Thermocline, north versus south: friend or foe. Aquatics 33(1)12-14.

[47] Whitford F, Becovitz J, Robertson B, MacGowan B, Blase G, Avenius B, Donahoe J, Zimmerman D, Blessing A. 2009. What killed the fish? Using observation, sampling, and science to solve the mystery. Purdue Extension Publication PPP-79. http:// www.ppp.purdue.edu/Pubs/PPP-79.pdf (accessed online 17 November 2012).

[48] Netherland MD. 2009. Chemical control of aquatic weeds. In: Gettys LA, Haller WT, Bellaud M. (eds.). Biology and control of aquatic plants: a best management practices handbook, pp. 65-77. Aquatic Ecosystem Restoration Foundation, Marietta, Georgia, USA.

[49] Haller B, Gettys L, Glenn M, Reynolds G. 2007. Building weighted trailing hoses. Aquatics 29(4):8-14. 
